\title{
SCIENCE:
}

Purlished by N. D. C. HOdGES, 874 Broadway, New York.

Subscriptions.- United States and Canada............\$3.50 a year. Great Britain and Europe............. 4.50 a year.

To any contributor, on request in advance, one hundred copies of the issue containing his article will be sent without charge. More copies will be supcontaining his article will be sent without charge. More copies will be supplied at about cost, also if ordered in advance. Reprints are not supplied, as ins reasons we desire to circulate as many copies of Science as pos sible. Authors are, however, at perfect liberty to have their articles reprinted elsewhere. For illustrations, drawings in black and white suitable for photoengraving should be supplied by the contributor. Rejected manuscripts will be returned to the authors only when the requisite amount of postage accompapies the manuscript. Whatever is intended for insertion must be authenticated by the name and address of the writer; not necessarily $f\urcorner r$ poblication, but as a guaranty of good faith. We do not hold ourselves responsible for any view or opinions expressed in the communications of our correspondents. Attention is called to the "Wants" column. It is invaluable to those Attention is called to the "Wants" colum. It is invaluable to those who use it in soliciting information or seeking new positions. The name and address of applicants should be given in full, so that answers will go direct to them. The "Exchange" column is likewise open.

\section{THE GREEN MOUNTAINS' ANTICLINAL}

BY C. H. HITCHCOCK, HANOVER, N.H.

THE key which is to unlock the intricacies of New England geology is to be found in the discovery of the proper structure of the Green and Hoosac Mountains. Hence in the occupation of this field for careful investigation the United States Geological Survey has acted wisely; and one cannot restrain impatience with the officials of the printing office, who have had the completed manuscripts descriptive of these results in their hands for more than two years, and have not published them.

The pioneers of American geology referred this Green Mountain range to the "Primary" series, chiefly because, in their view, all foliated crystalline rocks belonged there. Of course any sections illustrative of their notions from the theoretical standpoint would exhibit the anticlinal structure. But their actual illustrations, compiled from observation, do not support their theory: as shown by C. T. Jackson's section across the White and Green Mountains, and E. Hitchcock's sections across the Hoosac Muuntain. Hence it was that the geological literature of thirty and forty years' standing is pervaded with extreme applications of metamorphism. C. B. Adams, in the second report upon the geology of Vermont, in 1846 (p. 168), raised the query whether the occurrence of the quartz rock, limestone, and talcose schists upon the east side of the Green Mountains, in Plymouth and elsewhere, did not include the repetition of the Taconic rocks over an azoic foundation. $\mathrm{He}$ offered this suggestion as something worthy of investigation. His successors in the study of Vermont geology attempted to dis cover the structure of the mountains, as well as of all parts of the State, by measuring thirteen sections accoss the territory from east to west. A summary of the results was given by E. Hitchcock in the final report, page 252 ; from which it would appear that the structure of the Green Mountains was anticlinal. His contemporary, Logan, insisted that this structure was synclinal. The later studies of the writer, in several publications, confirm the first view, which is also held by Selwyn, the successor of Logan as director of the Canadian Geological Survey.

Having had occasion recently to examine the rocks of Hoosac Mountain and the neighborhood, the writer desires to offer the following observations. The excavation of the Hoosac tunnel has afforded us the opportunity of observing the structure of the interior of this mountain compared with what may be seen at the surface; and it was stated in Macfarlane's Railway Guide, 1879, that Hoosac "Mountain is believed to be an inverted and very much crushed anticlinal." Professor R. Pumpelly, in his paper upon secular rock-disintegration in the Bulletin of the Geological Society of America, vol. II., presents a map covering a part of this mountain, which shows the distribution, first, of a central core of granitoid gneiss; second, a coarsely foliated, often white, gneiss, supposed to be the dynamic product of a Cambrian conglomerate; third, the Hoosac schists, which wrap around and over the gneisses; and, fourth, the quartzite, which is the basal member of the Cambrian, known familiarly as the "granular quartz" of Emmons. The anticlinal fold is therefore easily recognized. The granitoid gneiss in the centre crops out upon the mountain a mile or so south of the tunnel, and the arch dips ten degrees northerly, and the rock is exposed where cut by the excavation. It is made up of blue quartz, large microcline crystals, somewhat elongated and assuming the augen habit, together with the green. ish mica, chlorite, and epidote of the foliation. It is said to be the equivalent of the gneiss of Clarksburg Mountain. The Vermont geology described this rock as the Stamford granite (gneiss) and speaks of it at several places farther north also. Our New Hampshire studies enable us to correlate this central granitoid augen gneiss with the "porphyritic granite, or gneiss," said to lie at the foundation of the stratigraphical column. In New Hampshire the mica is commonly biotite, while the greenish micas at the tunnel are more suggestive of the later protogene, called "Bethlehem gneiss." As the chloritic mineral is the result of alteration, its presence is not definitive. But the augen gneiss seems to constitute the foundation upon which the later gneisses were disposed in both localities.

There must be a decided unconformity between the augen and the overlying white conglomerate gneiss. This is shown not so much by a decided divergence in the angle of dip as by the general principle that a conglomerate is necessarily unconformable to the original rock from which the fragments have been derived. Some would say the augen gneiss was of igneous origin; and, if so, the discordance would be equally marked.

This Hoosac gneiss, or its equivalent, must be manifested in the Shelburne Falls anticlinal area, the Halifax-Reading ranges, and others farther east and north. Each range has the anticlinal attitude, while the intervening basins are of newer rocks. Next to the Green Mountains structure, the succession of gneissic waves capped by hornblende schist have aided us in working out the stratigraphy of the New England crystallines.

The proper place for the Hoosac schists may be an open question. E. Hitchcock, in his map of 1844, made the Graylock, Hoosac (west side), and the Charlemont schistose areas equivalents; and perhaps this is the most natural view. We must, however, remember that these hydro-micaceous and chloritic schists are not confined to a single horizon. There are, first, those of the Green Mountain gneiss, described as pre-Cambrian; second, those of the granular quartz, or Lower Cambrian; third, those of the Berkshire and Graylock terranes, as pointed out by Dale, and corresponding to the magnesian slate of Emmons. Hence there may be reason for the reference of the Hoosac schists to any of four different horizons that best explain the dips.

The Stockbridge limestone is evidently repeated on the east side of the anticlinal at Plymouth, Vt. Whether it once extended along the whole range and has been eroded, or is represented by an equivalent terrane, or is wanting, remains to be discovered.

\section{BOTANY AT THE EXPERIMENT STATIONS.}

BY GEORge F. ATKINSON, Botanical DePARTMENT, CORNELL UNIVERSTTY.

A REMARKABLE stimulus to botanical investigation has been given in the last few years through the opportunities offered by the organization of botanical departments at the various State experiment stations. The acquisition by the States of the congressional fund has afforded means, hitherto possessed only by a few favored institutions, for the purchase of the expensive apparatus and libraries of technical works needed in modern biological research. It also provides for the employment of men who devote part or the whole of their time to original study and the practical application of the results. The fund was designed not only for the purpose of treating economic botany in a practical way, but also for the purpose of pure science study, which in many cases must precede any practical treatment.

Studies of forage plants, of the improvement of sorts by the selection of seed, cross-fertilization, the distribution and harmfulness of weeds, the relations of micro organisms to the fertility of soils, besides many subjects appertaining more or less to horti- 